\title{
ソリトン共鳴により発生する大振幅ソリトンの解析
}

\section{Large Amplitude Internal Solitary Waves due to Solitary Resonance}

\author{
中山恵介 ${ }^{1} \cdot$ 柿沼太郎 $^{2} \cdot$ 辻 英一 $^{3}$ - 及川正行 ${ }^{4}$ \\ Keisuke NAKAYAMA, Taro KAKINUMA, Hidekazu TSUJI and Masayuki OIKAWA
}

\begin{abstract}
To clarify the resonance of fully-nonlinear internal solitary waves which is one of the reasons for the occurrence of large amplitude internal waves, fully-nonlinear and strongly-dispersive internal wave equation model was applied, which attempted to investigate interaction of internal solitary waves in a two-dimensional plane. The $3^{\text {rd }}$ order theoretical solutions for internal waves in a two-layer system was used for the initial conditions and progress of internal solitary wave was confirmed. Seven different incident wave angles were given, in which 'stem' was confirmed to appear when incident wave angle is less than critical angle. As a result, it is found that the amplified internal wave amplitude becomes about three times as much as the original amplitude.
\end{abstract}

\section{1. はじめに}

水面波の観測において，しばしば大振幅の波の発生が 確認されており，特に大きな振幅の波はfreak waveなど として知られ，多くの問題が未解決のままである。その 中で, 大振幅ソリトンの発生原因の一つとして, 強非線 形な孤立波の共鳴が考えられており, 弱非線形モデルを 利用して, 表面波・内部波を問わず2次元空間において 孤立波を干渉させることにより，与えた振幅の 4 倍にも およぶ内部波が発生することが報告されている（辻・及 川, 2006 ; Funakoshi, 1980). その大振幅の孤立波は, 2 波が干渉する際の臨界角度付近において誘起されるこ とが報告されている。しかし, それらの解は弱非線形の 方程式を利用して得られた結果であり, 強非線形・強分 散関係を考慮した孤立波同士の干涉を検討したものでは ない.

一方で，塩水と淡水および日射の影響により形成され る成層場における内部波にのみ着目すると, 同様な大振 幅の内部波が発生する可能性が指摘されている (Wallace • Wilkinson, 1988 ; Helfrich, 1992 ; Pierson • Weyhenmeyer, 1994 ; Antenucci • Imberger, 2001 ; Nakayama - Imberger, 2010). それらの研究は, 主とし て低周波の内部波が高埖波の内部波へと変形する際にソ リトン分裂し発生する内部波を取り扱ったものである. その中で, 大振幅の内部ソリトン波が斜面上で砕波する

\begin{tabular}{|c|c|c|}
\hline 1 正会員 & 博 (工) & 北見工業大学工学部教授 \\
\hline 2 正会員 & 博 (工) & $\begin{array}{l}\text { 社会環境工学科 } \\
\text { 鹿児島大学大学院准教授 } \\
\text { 理工学研究科 海洋土木工学専攻 }\end{array}$ \\
\hline 3 非会員 & 博 (理) & $\begin{array}{l}\text { 九州大学助教 } \\
\text { 応用力学研究所 }\end{array}$ \\
\hline 4 非会員 & 工博 & $\begin{array}{l}\text { 福岡工業大学教授 } \\
\text { 知能機械工学科 }\end{array}$ \\
\hline
\end{tabular}

ことにより底層の物質を巻き上げ，密度界面下において 発生する貫入現象により長期的な物質輸送が発生するこ とが指摘されており, 大振幅の内部ソリトン波の発生機 構解明が重要であることが指摘されている（Nakayama・ Imberger, 2010).

Choi ・ Camassa（1999）に代表される理論や，長波か ら発生するソリトン分裂に関して論じたHornら（2001） の研究が存在する（Holloway, 1997）が, 著者らは強非 線形・強分散の波の干涉を検討するための初期条件を与 えるために，9次オーダーの内部波の方程式（Mirie • Pennell, 1989) を利用して3次オーダまでの解を導出した (中山ら, 2010). その解の妥当性, 利用限界について, 強非線形強分散内部波モデル（柿沼, 2001 ; Nakayama・Kakinuma，2010）による再現性の検討を行 い, 強非線形・強分散関係を持つソリトンの再現計算に 成功した (中山ら, 2010). しかし，2次元空間において 孤立波が干渉することにより発生する, 振幅が4倍にも およぶ内部波について, 強非線形・強分散関係を考慮し ても同様に発生するかどうかについては不明である.

そこで本研究では, 3 次オーダ解を強非線形強分散内 部波モデルに利用して2次元平面におけるソリトンの干 渉を検討し, 大振幅ソリトンの発生について論じること を目的とする。

\section{2 次元平面における内部波の進行}

2波の干渉を解析するためには，2次元平面において内 部波が安定して進行することを確認しなくてはならな い. まず, 9 次オーダの内部波の方程式（Mirie • Pennell,1989）を利用して導出された3次オーダの波形の 解の主要な部分を以下に示す (図-1)。係数等の詳細は, 紙面の都合上省略するため, 中山ら（2010）をご覧いた だきたい。 


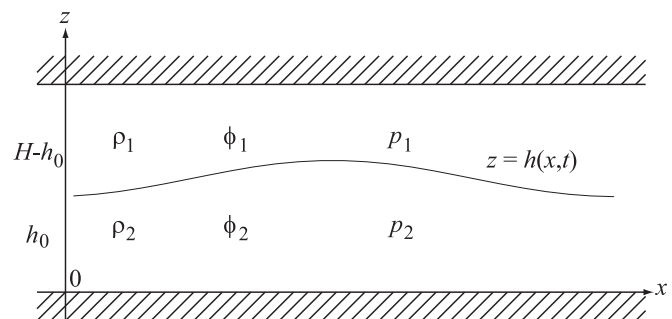

図-1 2層流体システム

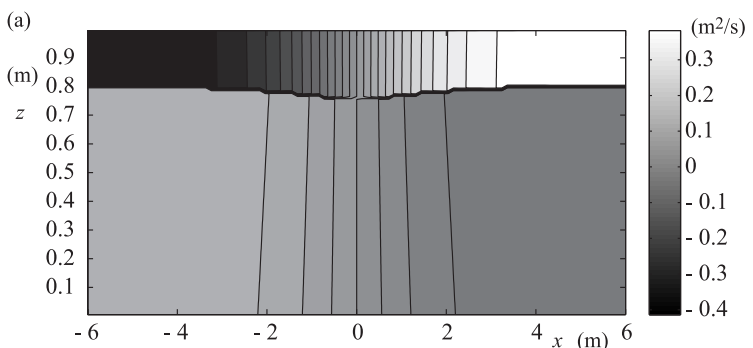

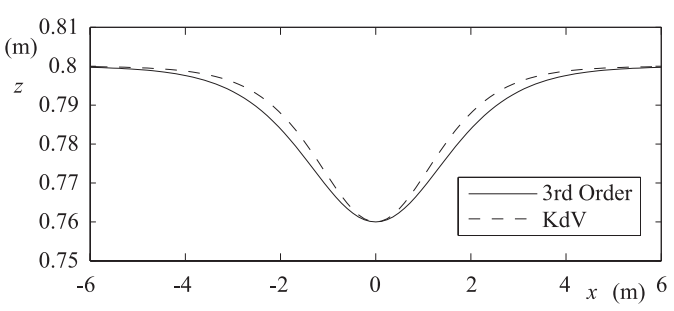

図-2 3 次オーダの孤立波解と $\mathrm{KdV}$ 理論解の比較

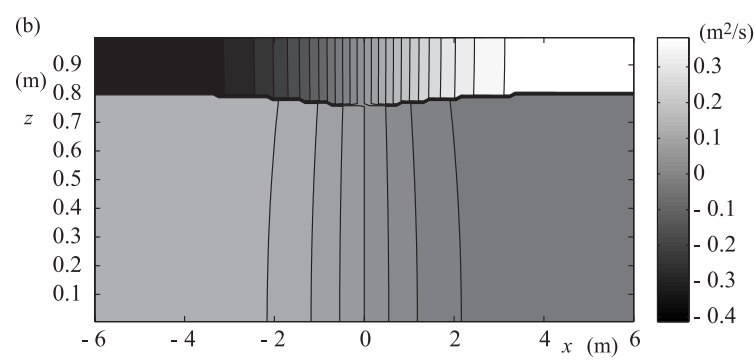

図-3（a）鉛直方向に対して2次の項まで考慮したべキ乗関数により再現された速度ポテンシャル

(b) 3次オーダ解による速度ポテンシャル

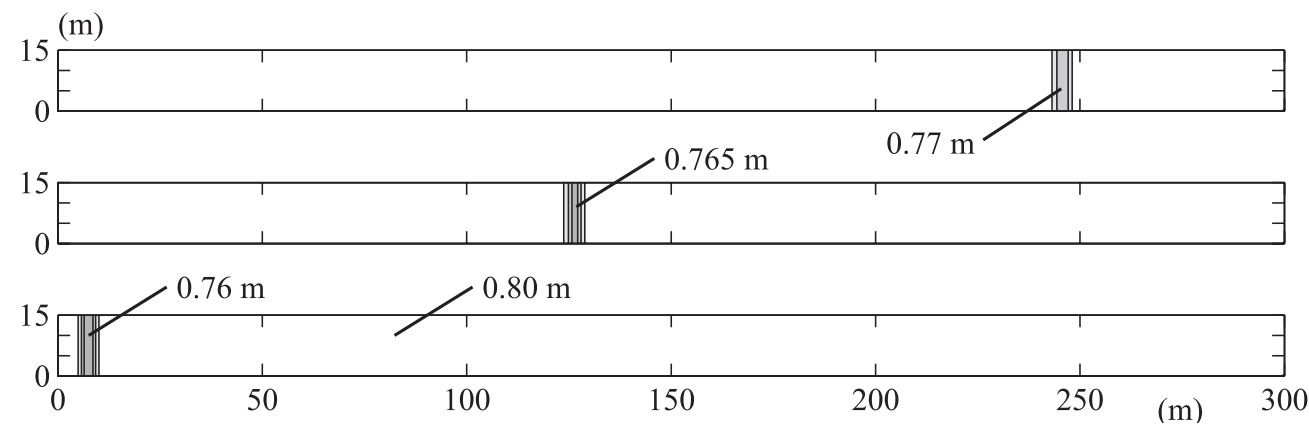

図-4 下から初期状態，100秒後，200秒後における密度界面のコンタ図
ここで， $\rho_{1}$ と $\rho_{2}$ は上層密度と下層密度， $H$ と $h_{0}$ は全層と 下層厚さ，（は界面変位， $p_{1}$ と $p_{2}$ は上層と下層の圧力， $a$ は振幅， $h$ は界面位置， $K$ は水平空間スケールに関する係 数, $A_{i j}(i, j=1 \sim 3)$ は界面変位に関する係数, $C_{i}(i=1 \sim 3)$ は波速に関する係数である。

対象とした内部ソリトン波の条件は，上層厚さ $0.20 \mathrm{~m}$, 下層厚さ $0.80 \mathrm{~m}$, 上層密度/下層密度 $=1.000 / 2.000$, 振幅 $=0.8 \times 0.05 \mathrm{~m}$ とした. Nakayama (2006), Nakayama • Kakinuma (2010), 中山ら（2010）により，振幅の大き な非線形性の強い3次オーダ解による内部ソリトン波は, KdV 理論による解よりも裾野が広がった形状として与え られることが知られている。本研究で与えた条件でも, 同様な傾向を確認することが出来た（図-2).

非回転場に扔ける2層流体の方程式である強非線形強 分散内部波モデルが, 速度ポテンシャルを $z$ のべき乗の 関数により再現することから，考慮する項数による再現 


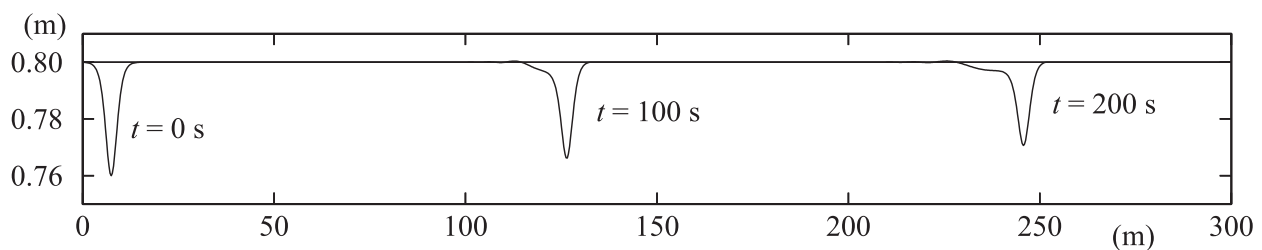

図-5＼cjkstart横断方向中央における界面位置の時間変化. 初期状態，100秒後，200秒後

(a)

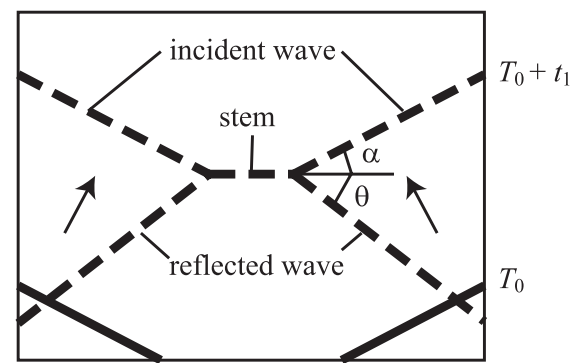

(b)

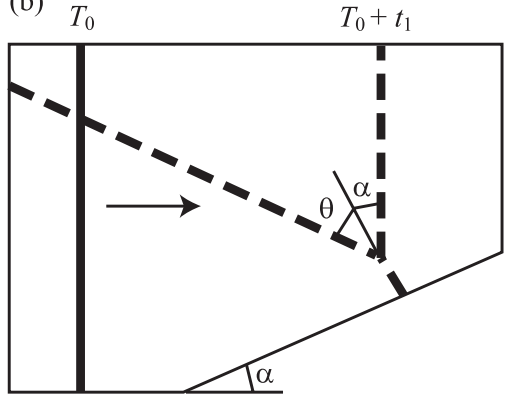

図-6（a）ソリトンの共鳴によるstem発生の概念図. $\alpha$ : 入射角. $\theta$ ：反射角. $T_{0}$ ：ある時刻. $t_{1}$ ：ある時刻から経過した時間 (b) Funakoshi（1980）によるstem発生計算領域

性の検討を行う必要がある.内部ソリトン波を再現する ために必要な計算メッシュ数は, 進行方向に対して 50 程 度であり，後ほど具体的に示すが，2次元平面における 内部ソリトン波の干渉に関する検討を行うためには, 最 低でも $1000 \times 500$ 程度のメッシュ数が必要となる．その ため, 計算機容量の制限から, べき乗の関数で再現する 際に利用する項数を 2 とした。速度ポテンシャルの再現 性の検討を行ってみたところ, 2 次の項まで考虑した速 度ポテンシャルの3 次オーダ解の再現性に関して, わず かながら異なる部分が見られるが，ほぼ良く再現できて いることが確認された（図-3）。また，考慮する項を2次 までとし計算の負担を減らしたが，全領域を対象とした 計算を実行することは計算機容量の制限から困難である ため, 対象計算領域を制限することとした．制限の方法 は，進行している内部ソリトン波を含む $45 \mathrm{~m}$ の幅のみの 計算を実施し，それ以外の領域にはスポンジ層を設けて エネルギーを減衰させるという方法である。

実際に2次の項まで考慮した強非線形強分散モデルが2 次元平面内に扔ける内部ソリトン波の進行を再現できる かどうかを確認するために，メッシュ数 $1000 \times 50$ $(300 \mathrm{~m} \times 15 \mathrm{~m})$ を与えて 200 秒間の再現計算を実施した (図-4).2 次元平面内に打けるコンタでみると，ほぼそ の形状が保たれているようにみえる。しかし，進行方向 の切断面に扔ける密度界面の時間変化から, 内部ソリト ン波の後方に，わずかながらであるが振幅の小さな波が 分離しつつあることが分かった（図-5)。中山ら（2010） により, 同様な計算条件で30秒程度は形状が保たれるこ とが報告されていたが，より長期の計算における安定性
の検討が必要であることが分かった.

\section{3. 境界条件の取り扱い方法の開発}

孤立波の 2 次元平面に扔ける干渉を再現する方法とし て，辻・及川（2006）を利用することが考えられる. そ のためにはデカルト座標系を斜めに横断する内部ソリト ン波を与えなくてはならない。 また, 斜めに交差する内 部ソリトン波の再現を行うためには, 交差角度にも依存 するが，一般的に膨大な計算領域を確保しなくてはなら ない，そこで本研究では，それらの問題を解決するため, Funakoshi（1980）による単一ソリトンの進行，反射によ り再現する方法を用いることとした（図-6).これにより， 2つのソリトンが臨界角度程度以下を持って干渉するこ とにより共鳴し合うと, 単一のソリトンよりも振幅の大 きなstemが発達する様子を再現できることとなる.

Funakoshi（1980）による方法を用いることで，計算 領域掞よび斜めに交差する内部ソリトン波の問題を解決 できるが，計算領域中に設置する，計算格子に対して傾 斜した壁における境界条件をどのように取り扱うべきか という問題を解決しなくてはならない.内部波の境界上 での反射を取り扱う方法として, Simanjuntak etc. and Nakayama（2010）により法線方向の流速をゼロとして 取り扱う手法が提案されている。本論文では速度ポテン シャルを変数として扱っていることから, 直接, その手 法を適用することはできない，そこで本論文では，同様 な考えに基づき，運動方程式を介して斜境界を取り扱 う埋め込久境界法を提案する (図-7). 法線方向の流速 はゼロでなくてはならないため, 式（10）を満たす必要 


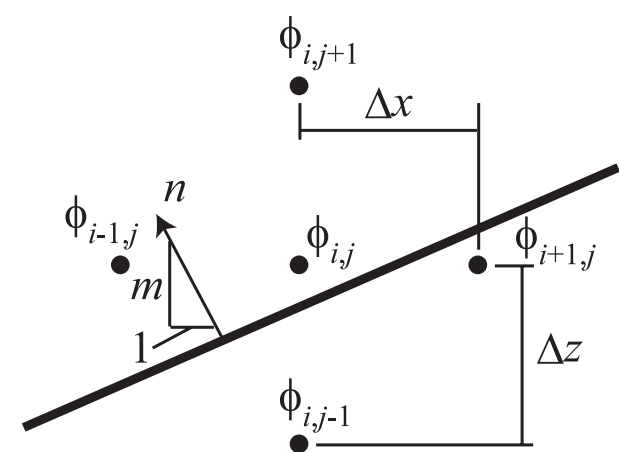

図-7 埋め达み境界の概念図

がある。

$$
\frac{\partial \phi}{\partial n}=\frac{\partial \phi}{\partial x} d x+\frac{\partial \phi}{\partial y} d y=0
$$

\section{ここで， $\phi$ は速度ポテンシャルである.}

つまり，壁の中と考えられる $\phi_{i+1, i}$ と $\phi_{i, i-1}$ を, 式 (11) および式（12）で与えることにより，境界における法線 方向の流速ゼロの条件を満たすこととなる.

$$
\begin{gathered}
\phi_{i+1, j}=\phi_{i, j}-m \frac{\phi_{i, j+1}-\phi_{i, j}}{\Delta y} \Delta x \\
\phi_{i, j-1}=\phi_{i, j}+\frac{1}{m} \frac{\phi_{i+1, j}-\phi_{i, j}}{\Delta x} \Delta y
\end{gathered}
$$

なお連続式に関して, 強非線形強分散方程式モデルに おいて保存系での取り扱いが出来ないため，矩形格子を 用いて連続関係が満足されるように取り扱うこととした。

\section{4. 解析結果}

上層・下層厚さを $0.2 \mathrm{~m}$ と $0.8 \mathrm{~m}$ ，上層・下層密度を 500 $\mathrm{kg} / \mathrm{m}^{3}$ と $1000 \mathrm{~kg} / \mathrm{m}^{3}$ ，振幅を下層厚さ $\times 0.05(=0.04 \mathrm{~m})$ と して与えた場合, 臨界角度は33.4度が得られる。stemは 臨界角度以下に扔いて発生するため, stem発生による再 現性の検証も含め, 計算条件として入射角度 10 度, 15 度, 20 度，25度，30度，35度，40度（case 1 から case 7 と呼 ぶ）を与えることとした。計算領域のメッシュ数は，そ れぞれのケースに扔いて $1400 \times 480(420 \mathrm{~m} \times 144 \mathrm{~m})$ ， $1200 \times 560(360 \mathrm{~m} \times 168 \mathrm{~m}), 1000 \times 600(300 \mathrm{~m} \times 180 \mathrm{~m})$, 以下 case 7 まで同じ条件とした。

\section{（1） stem 発生：case 1 から case 3}

臨界角度が 33.4 度であることから， case 1 から case 5 ま でに打いて stemの発生が予想された。しかし，明確な stemは case 1から case 3のみにおいて確認された（図-8）. 第2章で示された通り，内部ソリトン波の後方に振幅の 小さな波が分離する傾向にあり，内部ソリトン波の振幅 が減少してしまったことが関連していると考えられる.
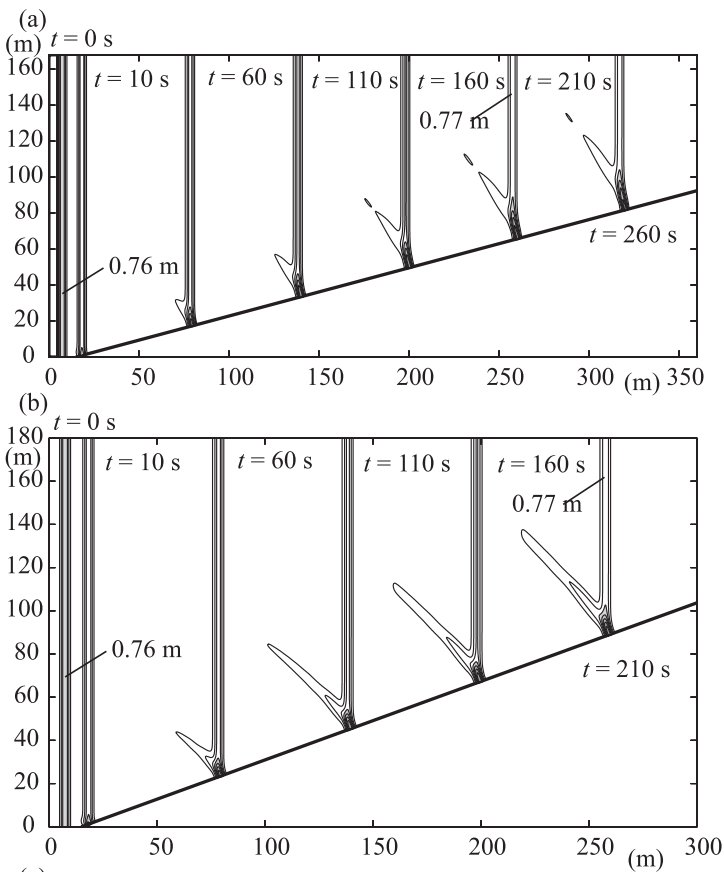

(c) $t=0 \mathrm{~s}$

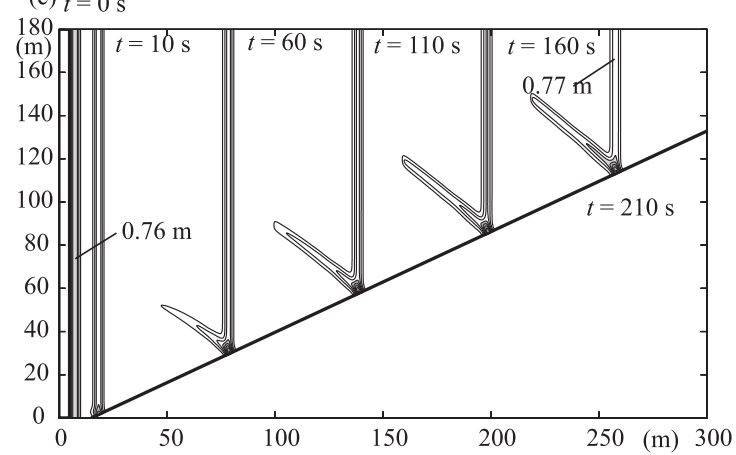

図-8 内部界面位置のコンタ.

(a) 入射角度 15 度（case 2) に扔ける内部ソリトン波の 時間変化 (260秒後まで50秒毎).

（b）入射角度 20 度（case 3）における内部ソリトン波の 時間変化 (210秒後まで50秒毎).

(c) 入射角度 25 度（case 4) における内部ソリトン波の 時間変化（210秒後まで50秒毎）

つまり，振幅の減少により臨界角度が小さくなり，理論 的に得られた臨界角度よりも小さな 30 度のケースに打い て stemが発生しなかったものと推測される. stemの発達 について case 2 と case 3 を比較すると，辻・及川（2006） に扔いて示されているように，入射角度が小さいcase 2 の方がより早く発達していることが確認された。また， case 2 ではstemがより長く発達するため, case 3 と比較し て反射波の発達に時間を要することが分かった.

\section{（2）振幅の増大率について}

内部界面位置のコンタから， case 4では十分に反射波

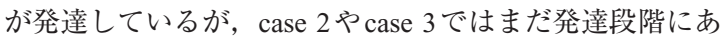




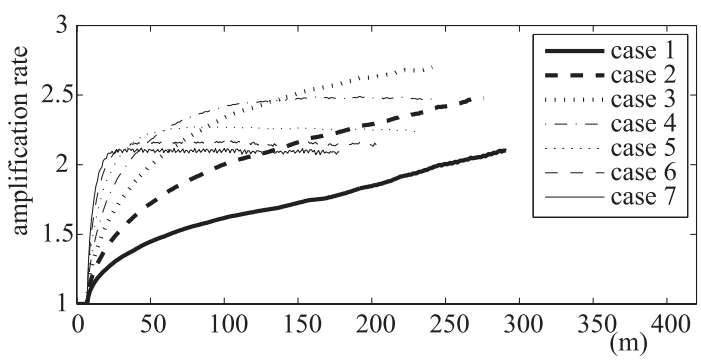

図-9 増幅率の時間変化. case 1 から case 7

るようにみえる（図-8)。そこで，内部ソリトン波の振幅 に対する最大振幅の比を計算し, 各ケースにおける増幅 率の時間変化を示す（図-9). case 4から case 7 まではあ る時間に達すると一定值に落ち着いている様子が示され ているが, case 1から case 3については増幅率が時間と共 に増大している途中であることが分かる.内部界面位置 のコンタにおいて示されたように，反射波が十分に発達 していないことからも, 特に入射角度が小さいcase 1で はより長時間の計算が必要であることが分かる.

今回採用した幾つかのケースに拉いて, 増幅率が2を 大きく超えており, freak waveとして存在するような波 が再現されていることが確認された．特にcase 3 は計算 領域の関倸から 230 秒程度までしか増幅率が計算されて いないが, 増加途中に扔いて増幅率2.7を超えており, 計算領域を大きくすることにより，より大きな増幅率を 再現することが出来ると考えられる，辻・及川（2006） により，KP方程式を利用することにより最大で増幅率は 4にまで達することが示されて抢り, 実際にFunakoshi （1980）は，定常状態に達しているかどうかの問題は残 るが, 数值計算により増幅率 3.5 まで確認している.し かし, KP方程式により得られる増幅率 4 は, 進行方向に 直交する成分に関して弱非線形を仮定していることや, 内部波について同様な適用性を確保できるかなどの疑問 が残っている.

今後, 安定した単一の内部ソリトン波の発生, 強非線 形強分散方程式モデルによる高次項を考慮した再現，よ り広い計算領域の確保により, 辻・及川（2006）が示し た増幅率との比較検討を行う必要がある。

\section{5. おわりに}

2 次元平面に㧍ける内部ソリトン波の干渉に関する検 討を行い, 以下のような結論を得た.

a）デカルト座標系において斜面境界を取り入れる方法 を提案した。 b） 2次元平面における内部ソリトン波の干渉による stem の発生を確認した。

c）内部ソリトン波が干渉することにより，KP理論でも 示されているような増幅率 2 以上の波を再現すること が出来た.

\section{参 考 文 献}

柿沼太郎（2001）：透水性海浜に抢ける内部波の挙動の数值計 算, 海岸工学論文集, 第48巻, pp. 146-150.

辻 英一・及川正行 (2006)：Extended Kadomtsev-Petviashvili 方程式の孤立波解の斜相互作用, 応用力学研究集会報告, No.17ME-S2, No.37.

中山恵介, 柿沼太郎, 及川正行, 辻 英一, 丸谷靖幸 (2010)： 内部ソリトン波の3次オーダー解による再現性の検討, 海 岸工学論文集, 第 57 卷, pp.1-5.

Antenucci, J.P. and J. Imberger. (2001) : Energetics of long internal gravity waves in large lakes, Limnology and Oceanography., Vol.46, pp. 1760-1773.

Choi W, and R. Camassa (1999) : Fully nonlinear internal waves in a two-fluid system, Journal of Fluid Mechanics., Vol. 396, pp. 136.

Funakoshi, M. (1980) : Reflection of obliquely incident solitary waves, Journal of the Physical Society of Japan, Vol.49, No.6, pp. 2371-2379.

Helfrich, K.R. (1992) : Internal solitary wave breaking and run-up on a uniform slope, Journal of Fluid Mechanics., Vol.243, pp. 133154.

Holloway, P.E., E. Pelinovsky, T. Talipova, and B. Barnes. (1997) : A nonlinear model of internal tide transformation on the Australian North West Shelf, Journal of Physical Oceanography., Vol.27, pp. 871-898.

Horn, D.A., J. Imberger, and G.N. Ivey. (2001) : The degeneration of large-scale interfacial gravity waves in lakes, Journal of Fluid Mechanics., Vol.434, pp. 181-207.

Mirie, R.M. and S.A. Pennell. (1989) : Internal solitary waves in a two-fluid system, Physics of Fluids, A1 (6), pp.986-991.

Nakayama K. (2006) : Comparisons of using CIP, compact and CIPCSL2 schemes for internal solitary waves, International Journal for Numerical Methods in Fluids, Vol.51, pp.197-219, doi: 10.1002/fld.1112.

Nakayama K. and T. Kakinuma. (2010) : Internal waves in a twolayer system using fully nonlinear internal-wave equations, International Journal for Numerical Methods in Fluids, Vol.62 (5), pp.574-590, doi: 10.1002/fld.2037.

Nakayama K. and J. Imberger. (2010) : Residual circulation due to internal waves shoaling on a slope, Limnology and Oceanography., Vol. 55, pp. 1009-1023.

Pierson, D.C., and G. A. Weyhenmeyer. (1994) : High resolution measurements of sediment resuspension above an accumulation bottom in a stratified lake, Hydrobiologia, Vol.284, pp. 43-57.

Simanjuntak M. A., J. Imberger and K. Nakayama (2009), Numerical wave drag due to stair-step topography in a geophysical flow model, Journal of Geophysical Research, 114, C12, doi: 10.1029/2008JC005051.

Wallace, B.C., and D. L. Wilkinson. (1988) : Run-up of internal waves on a gentle slope in a twolayered system, Journal of Fluid Mechanics., Vol.191, pp. 419-442. 